\title{
Screening household members of shepherds in brucellosis endemic areas in China and reporting follow-up results of asymptomatic infections
}

Jing $\mathrm{Hu}$

Jilin University School of Public Health

Huixin Yang

Jilin University School of Public Health

Xiangyi Zhang

Jilin University School of Public Health

Siwen Zhang

Jilin University School of Public Health

Taijun Wang

Jilin University School of Public Health

Jingjing Luo

Jilin University School of Public Health

Fangfang Hu

Jilin University School of Public Health

Dali Wang

Centers for Disease Control and Prevention Division

Shaonan Ni

Jilin University School of Public Health

Jian Sheng

Jilin University School of Public Health

Cui Zhang

Jilin University School of Public Health

Qing Zhen ( $\square$ zhenqing@jlu.edu.cn )

Jilin University School of Public Health https://orcid.org/0000-0002-2816-4539

Research article

Keywords: brucellosis, shepherds, asymptomatic infection, follow-up

Posted Date: June 7th, 2020

DOl: https://doi.org/10.21203/rs.3.rs-30753/v1 
License: (c) (i) This work is licensed under a Creative Commons Attribution 4.0 International License. Read Full License 


\section{Abstract}

Background: Brucellosis is a zoonotic infectious disease caused by brucella, patients often show obvious clinical manifestation, however, many cases of asymptomatic brucella infection were reported. Previous scholars have described or screened the asymptomatic infection, but little attention has been paid to the results. This research focused on the short-term results in patients with asymptomatic brucella infection

Methods. 595 household members of shepherds in brucellosis endemic areas were included, all of them have questionnaires and laboratory tests. Based on inclusion and exclusion criteria for the cohort, 15 asymptomatic infections were included and followed-up for 18 months.

Results: Among 595 subjects, 34(5.7\%) were asymptomatic infections, 460(77.3\%) were healthy, 58patients (9.7\%) were diagnosed as brucellosis, 13(2.2\%) suspected cases, 19(3.2\%) cured cases and $11(1.8 \%)$ unclear diagnosis. Among 15 asymptomatic infections, the median age was $34[12,50]$ years, there were $40 \%$ cases $<18$ years old and the male-female ratio was $1.5: 1,60 \%$ cases were farmers and herdsmen, $11(73.3 \%)$ cases had a history of possible exposure to brucella. Average follow-up time was $10.47 \pm 8.47$ months. A total of 7 asymptomatic infections developed into brucellosis, of which five patients turned in the first month of follow-up, one patient in the second month, and one minor case turned in the seventh month. Remaining asymptomatic infections showed negative outcomes after 7 months of follow-up, among them, SAT titer decreased in two cases, no changes in SAT titer and clinical manifestations in six cases.

Conclusions: Continued exposure to brucella may be a major risk factor for asymptomatic infection turn to brucellosis.

\section{Background}

Brucellosis is a common disease caused by infection of Brucella spp, which can be transferred from animals to humans ${ }^{[1,2]}$. It ranks as one of the most important zoonotic diseases throughout the world ${ }^{[3,4]}$. Brucellosis patients are often accompanied by long-term fever, hyperhidrosis, joint pain, hepatosplenomegaly or other clinical manifestation ${ }^{[5,6]}$. However, there are still many cases of asymptomatic brucella infection in endemic areas ${ }^{[7-9]}$ because of individuals who were continuously in contact with high risk animals were infected ${ }^{[10]}$. Asymptomatic infection is a condition of brucellosis. Although laboratory tests have confirmed brucella spp infection, subjects did not show any clinical manifestation. These subjects may present clinical manifestation in reinfection or immune deficiency conditions $^{[11]}$. December 2, 2019, the First Hospital of Lanzhou University reported that 4 researchers at the Veterinary Institute suspected of being infected with brucella. After standard agglutination test (SAT) titer test in 317 teachers and students of this institute, 96 people were found to be antibody positive, and none of them have clinical manifestation. They were all diagnosed as asymptomatic infection. 
The appearance of asymptomatic brucellosis infection has been reported in dozens of literatures. A study indicated that the prevalence of asymptomatic brucellosis infections in Saudi Arabian was 32.4\%[12], which was higher than that $(26.0 \%)$ from the study by Almuneeft al ${ }^{[13]}$. A survey in Iran showed that $53.3 \%(8 / 15)$ seropositive subjects had asymptomatic infection of Brucella ${ }^{[9]}$. Although these studies have carried out family screening or epidemiological characterization of asymptomatic infections, most have not conducted follow-up studies on results.

Our study searched brucella infections in family members of shepherds in endemic areas of China and described the results of follow-up of asymptomatic brucella infection for 18 months with the aim to provide more information on characteristics, results and positive result time of asymptomatic infection.

\section{Methods}

\section{Study population}

In November 2012, 595 subjects from shepherd families in Qianguoerluosi Mongolian Autonomous County, Songyuan District, Jilin Province, China were selected in this study by combination of multi-stage sampling for questionnaire survey. Meanwhile, blood samples were collected into vacuum tubes after the subjects signed the informed consent. Inclusion criteria for follow-up: laboratory serum agglutination test was positive (SAT > 1: $100++$ ) and had no clinical manifestations. Exclusion criteria for follow-up: patients who had previously been treated or disagreed with follow-up. 15 subjects remained.

\section{Follow-up}

These subjects were seen for follow-up once every three months until May 2014, with a total of 6 followup visits. Telephone interviews were taken, its main contents included whether the subject had clinical manifestations such as fever and fatigue, and whether he had contacted the sheep in some way, and reviewed SAT at the same time. Participants who developed clinical manifestation or whose SAT titer increased during the investigation were defined as positive result. On the contrary, participants who continued to be asymptomatic infection or whose SAT titer decrease within the time of follow up were defined as negative result.

\section{Laboratory test and data analysis}

SAT examinations were performed at Plague and Brucellosis Prevention and Control Base, Chinese Centers for Disease Control and Prevention. Epidata3.1 software was used to enter the questionnaire, and SPSS24.0 was used for statistical analysis. All tests were 2-tailed with a 0.05 significance level.

\section{Ethical support and quality control}

This study has been approved by the Ethics Committee of the School of Public Health of Jilin University. All participants were approved by the Institutional Review Board of the School of Public Health of Jilin University, signed an informed consent, and agreed to participate in the study. Professional training was 
provided to researchers. The diagnosis and serological methods and results of brucellosis were performed in accordance with relevant guidelines and regulations.

\section{Results}

A total of 595 subjects were included in the study and all of them were Questionnaire, interviewed, and then tested by SAT. Among them, $332(55.8 \%)$ cases were male and $263(44.2 \%)$ were female. The mean age was $33.81 \pm 18.12$, and $205(34.5 \%)$ subjects were under 18 years old. The distribution of brucella infection in 595 subjects was shown in Table 1.

Table 1

Brucella infection in 595 subjects

\begin{tabular}{|lll|}
\hline & Number & Percent (\%) \\
\hline Asymptomatic infection & 34 & 5.7 \\
\hline Confirmed case & 58 & 9.7 \\
\hline Healthy & 460 & 77.3 \\
\hline Suspected case & 13 & 2.2 \\
\hline Cured case & 19 & 3.2 \\
\hline Unclear diagnosis & 11 & 1.8 \\
\hline
\end{tabular}

Detailed baseline demographics of follow-up subjects were listed in Table 2. The male to female ratio was 1.5:1, and nine (60\%) were agro-pastoralists. The median age was 34 years (1st-3rd quartile: 1250 years), and six $(40 \%)$ subjects were under 18 years old. A majority $(n=11)$ of them has a history of potential exposure to brucella, such as contacting with abortion or brucella live attenuated vaccine, cleaning sheepfolds and delivering sheep. 
Table 2

General characteristics of 15 asymptomatic brucellosis infections

\begin{tabular}{|c|c|c|c|c|c|c|c|}
\hline \multirow[t]{2}{*}{ Characteristic } & \multirow[t]{2}{*}{ Total } & \multicolumn{3}{|l|}{ Male } & \multicolumn{3}{|l|}{ Female } \\
\hline & & $\leq$ & $\begin{array}{l}18- \\
30 \text { years }\end{array}$ & 30 years & $\leq$ & $\begin{array}{l}18- \\
30 \text { years }\end{array}$ & 30 years \\
\hline \multicolumn{8}{|l|}{ Occupation } \\
\hline agro-pastoralist & 9 & $0(0 \%)$ & $1(11.1 \%)$ & $5(55.6 \%)$ & $0(0 \%)$ & $0(0 \%)$ & $3(33.3 \%)$ \\
\hline student & 6 & $3(50 \%)$ & $0(0 \%)$ & $0(0 \%)$ & $3(50 \%)$ & $0(0 \%)$ & $0(0 \%)$ \\
\hline \multicolumn{8}{|c|}{$\begin{array}{l}\text { History of possible } \\
\text { exposure }\end{array}$} \\
\hline Raise sheep & 11 & $1(9.1 \%)$ & $1(9.1 \%)$ & $5(45.4 \%)$ & $1(9.1 \%)$ & $0(0 \%)$ & $3(27.3 \%)$ \\
\hline Deliver & 6 & $0(0 \%)$ & $1(16.7 \%)$ & $4(66.7 \%)$ & $0(0 \%)$ & $0(0 \%)$ & $1(16.7 \%)$ \\
\hline $\begin{array}{l}\text { Contact with } \\
\text { abortion }\end{array}$ & 4 & $0(0 \%)$ & $0(0 \%)$ & $2(50 \%)$ & $0(0 \%)$ & $0(0 \%)$ & $2(50 \%)$ \\
\hline $\begin{array}{l}\text { Contact with } \\
\text { vaccine }\end{array}$ & 5 & $0(0 \%)$ & $0(0 \%)$ & $3(60 \%)$ & $1(20 \%)$ & $0(0 \%)$ & $1(20 \%)$ \\
\hline Slaughter & 3 & $0(0 \%)$ & $0(0 \%)$ & $2(66.7 \%)$ & $0(0 \%)$ & $0(0 \%)$ & $1(33.3 \%)$ \\
\hline Clean sheepfold & 9 & $0(0 \%)$ & $1(11.1 \%)$ & $5(55.6 \%)$ & $0(0 \%)$ & $0(0 \%)$ & $3(33.3 \%)$ \\
\hline$N$ & 4 & $2(50 \%)$ & $0(0 \%)$ & $0(0 \%)$ & $2(50 \%)$ & $0(0 \%)$ & $0(0 \%)$ \\
\hline
\end{tabular}

Follow up results of 15 asymptomatic subjects were shown in Table 3. Of the nine adult infections, five patients were diagnosed as brucellosis in the first month, one patient was diagnosed in the second month, one of them was still asymptomatic and two subjects' SAT titer descend until the 18th month. Among the six juveniles, only one patient had obvious clinical manifestations in the seventh month, and the other five subjects were still asymptomatic at the end of 18-month follow-up. 
Table 3

Follow-up of 15 asymptomatic Brucella infections

\begin{tabular}{|c|c|c|c|c|c|c|}
\hline No. & Age & Sex & $\begin{array}{l}\text { Raising } \\
\text { sheep }\end{array}$ & $\begin{array}{l}\text { History of possible exposure during } \\
\text { follow-up }\end{array}$ & Outcome & $\begin{array}{l}\text { Follow- } \\
\text { up } \\
\text { (month) }\end{array}$ \\
\hline$x_{1}$ & $>30$ & Male & Yes & $\begin{array}{l}\text { Raise sheep, Graze, Deliver, Contact } \\
\text { with abortion, vaccine, Clean } \\
\text { sheepfold }\end{array}$ & $\begin{array}{l}\text { symptom } \\
\text { developed }\end{array}$ & 1 \\
\hline$x_{2}$ & $>30$ & Female & No & No & $\begin{array}{l}\text { symptom } \\
\text { developed }\end{array}$ & 2 \\
\hline$x_{3}$ & $>30$ & Male & Yes & Graze, vaccine, Clean sheepfold & $\begin{array}{l}\text { symptom } \\
\text { developed }\end{array}$ & 1 \\
\hline$X_{4}$ & $\begin{array}{l}\leq \\
18\end{array}$ & Female & No & No & $\begin{array}{l}\text { symptom } \\
\text { developed }\end{array}$ & 7 \\
\hline$X_{5}$ & $>30$ & Male & Yes & $\begin{array}{l}\text { Raise sheep, Graze, Deliver, Contact } \\
\text { with abortion, vaccine, Slaughter, } \\
\text { Clean sheepfold }\end{array}$ & $\begin{array}{l}\text { symptom } \\
\text { developed }\end{array}$ & 1 \\
\hline$x_{6}$ & $\begin{array}{l}18- \\
30\end{array}$ & Male & Yes & $\begin{array}{l}\text { Raise sheep, Graze, Deliver, Contact } \\
\text { with abortion, vaccine, Clean } \\
\text { sheepfold }\end{array}$ & $\begin{array}{l}\text { symptom } \\
\text { developed }\end{array}$ & 1 \\
\hline$x_{7}$ & $>30$ & Male & Yes & $\begin{array}{l}\text { Raise sheep, Graze, Deliver, Contact } \\
\text { with abortion, vaccine, Slaughter, } \\
\text { Clean sheepfold }\end{array}$ & $\begin{array}{l}\text { symptom } \\
\text { developed }\end{array}$ & 1 \\
\hline$x_{8}$ & $>30$ & Male & Yes & $\begin{array}{l}\text { Raise sheep, Graze, Deliver, vaccine, } \\
\text { Clean sheepfold }\end{array}$ & $\begin{array}{l}\text { SAT titer } \\
\text { descend }\end{array}$ & 18 \\
\hline$X_{9}$ & $>30$ & Female & Yes & $\begin{array}{l}\text { Raise sheep, Graze, Deliver, Contact } \\
\text { with abortion, vaccine, Clean } \\
\text { sheepfold }\end{array}$ & $\begin{array}{l}\text { SAT titer } \\
\text { descend }\end{array}$ & 18 \\
\hline$X_{10}$ & $\leq$ & Male & NA & NA & $\begin{array}{l}\text { Asymptomatic } \\
\text { infection }\end{array}$ & 18 \\
\hline$X_{11}$ & $\begin{array}{l}\leq \\
18\end{array}$ & Male & NA & NA & $\begin{array}{l}\text { Asymptomatic } \\
\text { infection }\end{array}$ & 18 \\
\hline$X_{12}$ & $\leq$ & Female & NA & NA & $\begin{array}{l}\text { Asymptomatic } \\
\text { infection }\end{array}$ & 18 \\
\hline$X_{13}$ & $\leq$ & Female & NA & NA & $\begin{array}{l}\text { Asymptomatic } \\
\text { infection }\end{array}$ & 18 \\
\hline$X_{14}$ & $\leq$ & Male & NA & NA & $\begin{array}{l}\text { Asymptomatic } \\
\text { infection }\end{array}$ & 18 \\
\hline$X_{15}$ & $>30$ & Female & Yes & $\begin{array}{l}\text { Raise sheep, Graze, Deliver, Contact } \\
\text { with abortion, vaccine }\end{array}$ & $\begin{array}{l}\text { Asymptomatic } \\
\text { infection }\end{array}$ & 18 \\
\hline
\end{tabular}




\section{Discussion}

Asymptomatic brucellosis patients may develop into brucellosis patients, causing serious damage to their health ${ }^{[14]}$. Nine farmers and herdsmen in this study may have been exposed to brucella through sheep raising, deliver, contact with aborted lambs and brucella live attenuated vaccine. These work methods give shepherds the opportunity to directly contact the liquid of diseased animals or the partially inactivated brucella, and to be exposed to the polluted environment for a long time, thus leading to infection. During this follow-up, it was found that a total of 7 (46.67\%) asymptomatic infections were positive and all showed obvious clinical manifestations of brucellosis, of which 5 patients turned positive in the first month. All 5 patients had an epidemiological history of exposure to diseased animals during the follow-up period, which may make them more likely to be exposed to brucella, it leads to repeated infection and progression from asymptomatic infection to brucellosis. There was one asymptomatic patient showed clinical manifestation after two months of follow-up, but she did not contact brucella directly during the follow-up period, the possible reason was the decline of the body's immune function. In addition. It was also found that two asymptomatic infection adults showed decreased SAT titers and no clinical manifestation. Possible causes were (1) Brucella antibodies had poor persistence in asymptomatic infections (2) Short follow-up time has not been observed the final outcomes of these two people.

Brucellosis reportedly occurs mainly in adult populations ${ }^{[10]}$. However, there were $6(40 \%)$ minors had asymptomatic infections in this study, most of them (83.3\%) had no brucella direct contact history. Possible causes of asymptomatic brucella infection in minors who were not in contact with diseased animals are (1) Minors have less direct contact with brucella, mainly due to ingestion of contaminated food or contaminated environment and aerosol infections ${ }^{[15-17]}$ such as eating unpasteurized dairy products and local traditional foods containing dairy products ${ }^{[18]}$. (2) Minors, especially children, usually show fewer or milder symptoms than adult patients. However, we also found that only one of the minors had a positive outcome at the seventh month at the same time. This may be due to the lower frequency of contact or contamination with brucella-bearing animals, and the possibility of repeated infection was lower.

We found that it is because of their continuous exposure to pathogenic animals or contaminated environments that asymptomatic infections had progressed from asymptomatic infection to brucellosis. For this asymptomatic brucella outbreak in the laboratory, we supposed that timely inspection and treatment of sources of infection should be performed to prevent asymptomatic infections from recontacting brucella and reduce the possibility of becoming infected. Similar happened in Thailand ${ }^{[19]}$.They also supposed that the most likely mechanism was air-borne inhalation. At the same time, researchers should strengthen personal protection in the search for the source of infection and terminal disinfection in order to avoid biosecurity issues from happening again. Follow-up observations should be performed on those diagnosed with asymptomatic infection. Fortunately, previous studies had 
shown that polymerase chain reaction (PCR) testing has an important role in predicting the subsequent outcome of asymptomatic brucella infection ${ }^{[20-23]}$.

There are several advantages in our study. First, the annual incidence rate of brucellosis in qianguoerluosi mongolian autonomous county was high, about 0.36 per thousand. It is a representative area with high incidence of brucellosis in China. Second, we surveyed all members of shepherds. However, only 15 asymptomatic infections were observed in our study, asymptomatic infection rates(5.7\%)are lower than previous studies $^{[9,24]}$. We supposed that the infection may show obvious clinical manifestation because of the strong virulence of sheep brucella. Previous research has shown that Brucella abortus is less pathogenic and virulent than sheep brucella, leading to asymptomatic and suspected infections in humans after exposure to infected cattle. Our current study also had limitations. First, we only observed 15 asymptomatic infections. Second, the average follow-up time was $10.47 \pm 8.47$ months, which only reflects the short-term outcomes of asymptomatic infections. Long-term outcomes and influencing factors cannot be obtained. Obviously, more cases and long-term follow-up can get more accurate results.

\section{Conclusion}

Continued exposure to brucella may be a major risk factor for asymptomatic infection turn to brucellosis.

\section{Declarations}

\section{Ethics approval and consent to participate}

This study has been approved by the Ethics Committee of the School of Public Health of Jilin University. All participants signed an informed consent and agreed to participate in the study.

\section{Consent to publication}

Written informed consent for publication was obtained from the patient.

\section{Availability of data and materials}

Not applicable.

\section{Competing interests}

The authors declare that they have no competing interest.

\section{Funding}

This study was supported by a competitive grant from Health Technology Innovation Project of Jilin Province, China (Project Number: 2016J076). The funding body had no role in database design, analysis, or writing the manuscript 


\section{Authors' Contributions}

ZQ, SN, CZ and JS: conception, Questionnaire design, acquisition analysis of data, interpretation of results, and manuscript writing. JH, HY, XZ, SZ, TW: acquisition of the data, interpretation of results, and revision of the manuscript. DW, $\mathrm{FH}, \mathrm{JL}$ : acquisition of the Laboratory examination results, interpretation of results, and revision of the manuscript. All authors read and approved the final manuscript.

\section{Acknowledgements}

The authors thank the Chinese Center for Disease Control and Prevention for accurate laboratory testing. In addition, the authors thank the team participants and employees for their valuable contributions, as well as the qianguoerluosi mongolian autonomous county government and the public for their cooperation.

\section{References}

1. Jia P, Joyner A. Human brucellosis occurrences in inner mongolia, China: a spatio-temporal distribution and ecological niche modeling approach[J]. BMC Infect Dis, 2015, 1536.

2. Franco M-P, Mulder M, Gilman R-H, et al. Human brucellosis[J]. Lancet Infect Dis. 2007;7(12):775-86.

3. Lai S, Zhou H, Xiong W, et al. Changing Epidemiology of Human Brucellosis, China, 1955-2014[J]. Emerg Infect Dis. 2017;23(2):184-94.

4. Golshani M, Buozari S. A review of Brucellosis in Iran: Epidemiology, Risk Factors, Diagnosis, Control, and Prevention[J]. Iran Biomed J. 2017;21(6):349-59.

5. Dean A-S, Crump L, Greter H, et al. Clinical manifestations of human brucellosis: a systematic review and meta-analysis[J]. PLoS Negl Trop Dis, 2012, 6(12): e1929.

6. Ulu-Kilic A, Metan G, Alp E. Clinical presentations and diagnosis of brucellosis[J]. Recent Pat Antiinfect Drug Discov. 2013;8(1):34-41.

7. Megged O, Chazan B, Ganem A, et al. Brucellosis Outbreak in Children and Adults in Two Areas in Israel[J]. Am J Trop Med Hyg. 2016;95(1):31-4.

8. Wang W, Liao Q, Wu X, et al. Potential risk of blood transfusion-transmitted brucellosis in an endemic area of China[J]. Transfusion. 2015;55(3):586-92.

9. Sofian M, Safaeipour L, Aghakhani A, et al. Screening of family members of patients with acute brucellosis in an endemic area of Iran[J]. Iran J Microbiol. 2013;5(3):215-9.

10. Pappas G, Papadimitriou P, Akritidis N, et al. The new global map of human brucellosis[J]. Lancet Infect Dis. 2006;6(2):91-9.

11. Zhen Q, Lu Y, Yuan X, et al. Asymptomatic brucellosis infection in humans: implications for diagnosis and prevention[J]. Clin Microbiol Infect. 2013;19(9):E395-7.

12. Alsubaie $S$, Almuneef $M$, Alshaalan $M$, et al. Acute brucellosis in Saudi families: relationship between brucella serology and clinical symptoms[J]. Int J Infect Dis. 2005;9(4):218-24. 
13. Almuneef M-A, Memish Z-A, Balkhy H-H, et al. Importance of screening household members of acute brucellosis cases in endemic areas[J]. Epidemiol Infect. 2004;132(3):533-40.

14. Celebi G, Kulah C, Kilic S, et al. Asymptomatic Brucella bacteraemia and isolation of Brucella melitensis biovar 3 from human breast milk[J]. Scand J Infect Dis. 2007;39(3):205-8.

15. Byndloss M-X, Tsolis R-M. Brucella spp. Virulence Factors and Immunity[J]. Annu Rev Anim Biosci, 2016, 4111-127.

16. Kahl-McDonagh M-M, Arenas-Gamboa A-M, Ficht T-A. Aerosol infection of BALB/c mice with Brucella melitensis and Brucella abortus and protective efficacy against aerosol challenge[J]. Infect Immun. 2007;75(10):4923-32.

17. Makis A-C, Pappas G, Galanakis E, et al. Brucellosis in infant after familial outbreak[J]. Emerg Infect Dis. 2008;14(8):1319-20.

18. Roushan M-R, Amiri M-J. Update on childhood brucellosis[J]. Recent Pat Antiinfect Drug Discov. 2013;8(1):42-6.

19. Tantisiriwat W, Buppanharun W, Santiwatanakul S, et al. Outbreak of Occupational Brucellosis in a Laboratory Technician at Her Royal Highness Princess Sirindhorn Medical Center, Srinakharinwirot University, Thailand[J]. J Med Assoc Thai. 2016;99(Suppl 8S):158-65.

20. Zeybek H, Acikgoz Z-C, Dal T, et al. Optimization and validation of a real-time polymerase chain reaction protocol for the diagnosis of human brucellosis[J]. Folia Microbiol (Praha). 2020;65(2):35361.

21. Maas K-S, Mendez M, Zavaleta M, et al. Evaluation of brucellosis by PCR and persistence after treatment in patients returning to the hospital for follow-up[J]. Am J Trop Med Hyg. 2007;76(4):698702.

22. Navarro E, Segura J-C, Castano M-J, et al. Use of real-time quantitative polymerase chain reaction to monitor the evolution of Brucella melitensis DNA load during therapy and post-therapy follow-up in patients with brucellosis[J]. Clin Infect Dis. 2006;42(9):1266-73.

23. Vrioni G, Pappas G, Priavali E, et al. An eternal microbe: Brucella DNA load persists for years after clinical cure[J]. Clin Infect Dis. 2008;46(12):e131-6.

24. Deniz S, Baykam N, Celikbas A, et al. Screening Household Members of Acute Brucellosis Cases in Endemic Areas and Risk Factors for Brucellosis[J]. Vector Borne Zoonotic Dis. 2015;15(8):468-72. 